AWEJ for Translation \& Literary Studies, Volume 6, Number1. February 2022 DOI: http://dx.doi.org/10.24093/awejtls/vol6no1.7

Pp.88-103

\title{
Prismatic Identities or Authentic Selves? Elif Shafak's Three Daughters of Eve: A perspective of Intersectional Feminism
}

\author{
Shuaa S. Al-Zahrani \\ Department of European Languages \& Literature, Collage of Arts \& Humanities, \\ King Abdulaziz University, Jeddah, Saudi Arabia \\ Laila. M. Al-Sharqi \\ Department of European Languages \& Literature, Collage of Arts \& Humanities, \\ King Abdulaziz University, Jeddah, Saudi Arabia \\ Corresponding Author: laila.alsharqi@gmail.com
}

Received: 10/27/2021

Accepted: $1 / 28 / 2022$

Published: $2 / 24 / 2022$

\begin{abstract}
Elif Shafak's novel Three Daughters of Eve(2016), questions contemporary assumptions concerning women's status in Islam and society. This study explores Eve's daughters-Peri, Shirin, and Mona - to investigate how gender, religion, and culture overlap and stereotypes intertwine in the novel to create unique experiences, values, beliefs, and challenges in the lives of women. This study argues that Shafak's inclusion of these overlapping aspects provides a basis for intersectional feminist discourse as a framework for understanding the complex nature of identity and self-understanding among women in the Middle East. The results of this study contribute significantly to the existing literature by demonstrating how the three females in the novel function as distinct self-identities through which Shafak negotiates assumptions of Western society about women and Islam. The study concludes that Shafak's work, giving voice to her women elevates aspects of diversity and inclusion by revealing the various guises of discrimination against them and illustrating how these women find ways to project their unique voices and resist oppression.
\end{abstract}

Keywords: Elif Shafak, feminism, gender, identity, intersectionality, Islam, religion, Three Daughters of Eve,

Cite as: Al-Zahrani, S. S., \& Al-Sharqi, L. M. (2022). Prismatic Identities or Authentic Selves? Elif Shafak's Three Daughters of Eve:

A perspective of Intersectional Feminism . Arab World English Journal for Translation \& Literary Studies 6(1) 88-103. DOI: http://dx.doi.org/10.24093/awejtls/vol6no1.7 
AWEJ for Translation \& Literary Studies Volume, 6 Number 1. February 2022

Prismatic Identities or Authentic Selves? Elif Shafak's Three Daughters of Eve

Al-Zahrani\& Al-Sharqi

\section{Introduction}

Elif Shafak (1971-Present) is an award-winning novelist, also recognized as an activist who stands for the rights of women, minorities, and freedom of speech. Like Orhan Pamuk and Sabahattin Ali, Shafak is one of the most prominent Turkish writers who have discussed controversial issues related to politics, religion, and violence against women and children. Employing elements of history, philosophy, and Sufism, Shafak's fictional and non-fictional works, written chiefly in Turkish and English, serve as a platform for narrating stories of immigrants, minorities, women, and subcultures. As one of the most widely read female authors in Turkey, Shafak's fictional works include The Gaze (1999), The Bastard of Istanbul (2006). Her most famous work, however, is Three Daughters of Eve (2016), a work that addresses a variety of issues related to politics, identity, and gender through the exploration of themes of faith and doubt, past and present, and the religious and secular.

In her most recent work, Three Daughters of Eve, Shafak traces the life experiences of three women, "the believer, the confused, and the sinner" (Shafak, 2016, p. 212) on their journey as students at Oxford University. She depicts the conflict that the three women experience regarding their identity as Muslim women, beginning with Peri, "the confused" heroine, who grows up in a chaotic household negatively impacted by the conflict between her secular, alcoholic father and her extremist, resentful mother. When moving to Oxford, the teenager Peri meets Shirin, a confident woman born in Iran but also moved to live in Oxford. Lacking a sense of belonging, Peri and Shirin meet with Mona, an Egyptian-American who proudly identifies as a religious feminist. In their attempt to discover their true beliefs, all three women decide to take the same seminar on God, though at different times, provided by Azur, an influencing instructor who introduces controversial arguments and ideas about God, good and evil, science and faith, existence and mortality. Throughout the novel, Shafak traces the three women through searching for their true selves. While Mona takes a firm stance towards her ideas, Shirin never accepts how her own beliefs define her. Instead, she attempts to justify her behavior and attributes by instigating a random dialogue that ends in cruelty and a fight with Mona. Meanwhile, Peri spends most of the time watching Mona and Shirin, remaining just as confused as to when she would watch her parents argue. She is positioned between Shirin and Mona, just as she was with her mother and father. Consequently, Peri never discovers her true self or comprehends the structure of her identity.

In her novel, Shafak portrays her female protagonists' struggle to break the stereotypes associated with gender, racial and religious-based identifications as they repeatedly challenge religious and cultural stereotypes that intersect in the continual battle against discrimination. As representatives of Muslim women in the novel, Shafak's three female protagonists face gender discrimination in various spheres of their life, the most significant challenges that women encounter daily, whether it is based on religion or on Western assumptions that Muslim women need to be "saved" from male domination. Oswald et al., (2012) define gender discrimination as experiences of "hostile sexism" women undergo by their family members, friends, teachers, coworkers, or strangers. These experiences impact females' body image and self-esteem, placing young women in a challenging mental state that negatively affects their wellbeing (Oswald et al., 2012). Shafak introduces an intersectional feminist perspective to mirror this notion by asserting 
women's diverse experiences in combatting sexist beliefs and gender discrimination. Besides, Shafak explores Muslim women's experiences of compounded levels of discrimination based on their religion, mainly due to Islamophobia, in their struggle to develop their identity and selfimage. Constructed by interlocking systems of oppression encompassing distinct forms of abuse and modes of resistance, this intersectional approach promotes acknowledgment of women's political identities (e.g., gender, ethnicity, religion, and class) and the potential ways these can impact how women experience oppression and discrimination (Crenshaw, 1989). Eve's Three Daughters share the same political identity (gender, ethnicity, and religion), yet each has a unique personality and interpretation of life. Therefore, while Shafak portrays the difficulties that Muslim women encounter due to their faith and gender identity, she also represents their multifaceted beliefs and assumptions regarding Islam and women, thus reflecting intersectional feminism's concerns with the ways in which factors such as gender and religion intersect.

Since this novel has not been thoroughly examined, this study aims to provide a thorough analysis of Shafak's exploration of women in Islam and society, who are often stereotyped as powerless and emotional with an inability to think clearly or needing a male figure to protect them. They are assigned specific roles and identifications related to their traits, physical appearance, domestic behavior, or occupation. For a long time, women have been forced to meet these expectations, as subordinate to men in an androcentric society. Hence, some men feel responsible for protecting women or feel this obligation so intensely that it may result in violent behavior. As Shirin asserts, if a strong woman states that "I can defend my own rights ... [we women] don't need a higher authority to do that for us!," some men will believe, even then, that women need "a strong leader [who] defends women's rights" (Shafak, 2016, p. 144). Thus, men sometimes consider themselves a necessary "higher authority" and "strong leader" because women are deemed powerless without a male to secure their rights for them. By revealing how her novel demonstrates the overlapping identity structure of Eve's three daughters within the context of intersectional feminism, this study hopes to highlight the constructs of gender and religion influence the three characters' self-identity, thereby revealing how although these characters share specific characteristics, each of Eve's daughters has distinct experiences. This fact shows how factors (e.g., gender, religion, and ethnicity) intersect to shape women's identities, impact their self-identity, and instigate diversity and inclusivity among women. This perspective ensures that intersectional feminism promotes the distinct experiences of women worldwide while also unveiling varied modes of discrimination, oppression, and ways to resist injustice. Intersectional feminist theory is a crucial contribution to the study of identities as it explores how religion and gender intersect and how identities are uniquely shaped and impacted. Therefore, this study employs aspects of intersectional feminist theory that acknowledge that women's identities are limitless, unique, and constructed on multiple factors.

\section{Theoretical Context}

In "Demarginalizing the intersection of race and sex: A black feminist critique of antidiscrimination doctrine, feminist theory, and antiracist politics" (Crenshaw, 1989, p. 152), Kimberlé Crenshaw defines intersectionality as a metaphor for understanding the ways that multiple forms of inequality that compound in the lived experiences of individuals and are not understood in the conventional ways of thinking or defined within a single parameter such as 
AWEJ for Translation \& Literary Studies Volume, 6 Number 1. February 2022

racism or feminism. She argues that the lived experiences of discrimination differ from one individual to another, but the limited nature of the current definition of discrimination allows for the marginalization of those with experiences that cannot be defined within such narrow parameters. This is particularly emphasized by Hooks (1982), one of Crenshaw's influencers, who challenges the middle-class white feminists who fail to acknowledge the intertwined relationship between race and class (Hooks, 1982). Crenshaw also explains that besides the disregard that women of color often receive, their oppression becomes amplified when white women speak about themselves as women. Feminists continue to ignore how their race functions to alleviate certain aspects of sexism and how it often privileges them, thereby contributing to the domination of other women (Crenshaw, 1989). As a result, feminist philosophy remains "white," while its ability to expand and deepen research into underprivileged women remains neglected. Thus, Crenshaw promotes intersectionality to spread awareness of the different experiences of all women.

Patricia Collins (2015) in “Intersectionality's definitional dilemmas," a study on feminism, gender, social inequality, sexuality, and nationhood in the African-American community, explains that individuals and groups are placed within intersecting systems of power in different ways and, thus, have distinct points of view. According to Collins, the best method for analyzing aspects of race, gender, age, nation, ethnicity) is to treat them in relational terms rather than treating each axis in isolation (Collins, 2015). Analyzing how each of these forms of oppression intersect with one another is essential to understanding the root causes for acts of discrimination and oppressive behavior against individuals who possess multiple identity categories (Collins, 2015). This is due to the meaning ascribed to these identities depends on how they are formed within various sociocultural contexts. Collins (2015) explains how intersectional theory considers the traditional family structure, which impacts political identities and shapes experience equally. He argues that the conventional family archetype functions as a privileged paradigm of intersectionality in the United States rather than an exploration of gender, race, class, and nationhood in the form of distinct social hierarchies that mutually construct one another. The study examines how the scope of intersectionality demonstrates precise associations between family, as a gender-based structure of the social organization, racial ideas, and practices, and the constructions of national identity in the United States. Collins's results support an intersectionality-based perspective, which holds that multiple identities form unique experiences that cannot be separated by each identity (Collins, 2015). Collins asserts that the traditional family archetype consists of a couple (i.e., a male considered the family provider and a stay-at-home wife) who procreate to produce biological children (Collins, 2015). As a result, women's roles are restricted to the private sphere of their home, while men exist in a public work environment, this being a model of the family that accepts the traditional separation of work and family life. According to Collins, the ideology of this conventional family structure transcends to social institutions within the United States (Collins, 2015); thus, for example, the structuring of social organizations and social policy is often accomplished through a family oratory structure. Moreover, Collins suggests that families create a sense of belonging among various groups: "to the family as an assumed biological entity; to geographically identifiable, racially segregated neighborhoods conceptualized as imagined families; to so-called racial families codified in science and law, and to the U.S. nation-state conceptualized as a national family" (Collins, 2015, p. 63). Therefore, families are considered a 
AWEJ for Translation \& Literary Studies Volume, 6 Number 1. February 2022

powerful group/team, given that social institutions, policies, and organizations are understood as important places for individuals (Collins, 2015).

In intersectionality, Collins and Bilge (2016) further analyze the relationship between identity politics and intersectionality as a form of analytical inquiry and practice. They assert that for many scholars, intersectionality is recognized as a theory of identity because it centers around identity. Collins and Bilge consider individuals to be combinations of their multiple identities (e.g., gender, sexuality, race, ethnicity, and religion) across different situations (Collins \& Bilge, 2016). Thus, intersectionality appreciates the abundance of various identities that create unique individuals and emphasizes the notion of overlapping identities. But due to an exaggeration of the concept of identity, several critics have interpreted intersectionality as inherent and recommend abandoning the stress on this notion. (Collins \& Bilge, 2016), but identity is essential when it comes to structuring a collective "we." Political identity, for example, relies upon the iterative connection between an individual and social structure, as well as between people "as an existing collective or a collective that must be brought into being because they share similar social locations within power relations. A transformed individual identity is potentially transformative and longlasting" (Collins \& Bilge, 2016, p. 206). When people change individually, they tend to stay that way. Focusing on the self and its wholeness offers a significant boost to an individual and contributes to a sense of collective independence (Collins \& Bilge, 2016). Since $i$ dentity is a defining feature of intersectionality, the use of intersectionality as a critical method thus, illuminates the complexity of people's lives within an equally convoluted social context.

Carastathis (2008) is another critic who examines the model of identities and argues for the significance of intersectional theories in analyzing identity Carastathis' study demonstrates how the analysis of identity may be conducted within a theoretical framework and illustrates that identity emerges from intersecting factors of political inclusion. She holds that intersectionality is the leading metaphor for multifaceted identities composed of gender, ethnicity, race, class, and sexual orientation. Carastathis explains that in feminist spheres, "post-identarian feminists" and "identitarians" (Carastathis, 2008, p. 24) employ the language of intersectionality, which effectively serve as a synonym for the "litany" of oppression, based on factors such as gender, race, class, sexuality, and disability. Thus, the term "intersectionality" inflects and informs in a way that increases its common usage. It becomes acceptable to use the term without accurately identifying what is being intersected or how this is occurring (Carastathis, 2008). Carastathis suggests that political identity is produced in and through political representation and that identities are the products of political relations (Carastathis, 2008). The task, then, is not to re-portray or improve the presentation of identities but to theoretically disclose it, modifying the relations that produce identities (Carastathis, 2008).

Carastathis (2013) continues to argue that theorizing identity categories as coalitions are important as identities "are often contrasted with coalitional politics in that the former is viewed as a kind of separatism based on sameness while the latter depends on alliances built across differences" (Carastathis, 2013, p. 941). Intersectional critics of identity distinguish between identity and coalition, focusing on the differences between and within groups (Carastathis, 2013). Carastathis' study illuminates the relationship between identities and intersectional theory, as 
theorizing about identity "coalitionally"(Carastathis, 2013, p. 942) allows for the surmounting of some of the challenges involving political coalitions that are structured on the principle of homogeneous, or essential, identities. Combining all aspects of individuals' identities is crucial to achieving the internal balance that is missing in "one-dimensional" political movements (Carastathis, 2013, p. 942). Carastathis also explains that people are asked to repress one or more aspects of their identities that a "monocular" (Carastathis, 2013, p. 942) analysis recognizes as significant. As a result, people foreclose on a potential coalition with others who share their suppressed or excluded identities. Carastathis suggests that Crenshaw's theory of identities as "coalitions" inspires people to "summon the courage" to challenge excluded aspects that marginalize them while constructing other people as representative, or archetypal, of entire groups, communities, or movements (Carastathis, 2013, p. 945). Carastathis further suggests that considering identity through the perspective of intersectional theory reveals identity to be multifaceted, an individual's identity being structured by the combination of various intersecting aspects. The study also suggests that excluding any aspect that defines a person's identity or discriminating against a person based on any element that constructs their identity might force them to hide their authentic self.

Linking the discussions above to Muslim society maps the intersectional narrative in Shafak's novel and her representation of the multifaceted assumptions regarding Islam and women and the difficulties Muslim women encounter due to their religion and gender identity. It is also significant to draw attention to Mirza's (2012) notion of "embodied intersectionality" as an essential framework for understanding how women are perceived as "visible Muslim others in discourse", and to how this representation is articulated and signified by the body and experienced as an empirical reality through women's subjectivity and sense of self" (Mirza, 2012, p.13).

\section{Three Daughters of Eve and Intersectional Analysis}

Various religious backgrounds and views are illustrated through Eve's daughters, who either face religious conflict within themselves or with those around them. Although being a Muslim and a woman are identities that intersect, the experiences and struggles of each daughter are unique. In Three Daughters of Eve, Shafak depicts how the discrimination that women face leads them to conceal essential facets of their identity. For example, Peri hides behind her true self due to a fear of being criticized or discriminated against by the people around her, including her family and friends. At the same time, Shirin struggles to exclude part of her identity. In addition, Shafak portrays different female characters to illustrate how multiple female identities are constructed about in relation to political identities, as well as how women intersect with a single aspect in different ways, creating unique identities. Shafak thus utilizes her writing as a tool to change the reader's perspective of others.

This idea is expressed by Nihad (2019) who states that Shafak writes to be a voice for passive figures that remain marginalized and othered in the shadows. To reveal to the world that these figures exist and have voices, Shafak conveys their religious, ethnic, or cultural affiliation to create "conceptions of [a] cosmopolitan and ... global village" (Nihad, 2019, p. 2908). Shafak grew up in a Turkish society, which has a "dual identity, religious affiliation, continental belonging and multicultural traits,... connect[ing] the Islamic Middle East and Christian Europe," a milieu 
AWEJ for Translation \& Literary Studies Volume, 6 Number 1. February 2022

that has led some to treat those with diverse characteristics as "the Other" (Nihad, 2019, p. 2901). Shafak has reflected these ideas in her literary works.

Bădulescu (2018) analyzes the three female characters in Three Daughters of Eve suggesting that each character may represent one of the three different stages that a person undergoes in life when impacted by both religion and skepticism, as well as the West and East (Bădulescu, 2018). For example, as Bădulescu indicates, Peri floats in a state of confusion, wi thout an understanding of where she belongs, just as Turkey straddles Europe and Asia to cruelly divide the West and East (Bădulescu, 2018). Likewise, Sarbu and Kosa (2019) characterize Professor Azur as "The Figure of the Seducer" and analyze the influence he has on Eve's daughters by way of his teaching and seduction methods (Sârbu \& Kosa, 2019, p. 149). Sarbu and Kosa compare Azur to the Byronic hero Don Juan and suggest that Azur is a twenty-first-century Byronic hero, who is uniquely observed by each of Eve's three daughters and whose image is reflected in their personalities: "he is a seducer for Shirin, a peace seeker for Mona and a storyteller for Peri" (Sârbu \& Kosa, 2019, p. 155). Sarbu and Kosa explore Shafak's way of structuring Azur —who separates his weakness from society, gradually withdrawing to maintain his secrets - as well as the three female protagonists, who individually interpret religion and react to Azur's attitude in distinctive ways.

\section{Peri, the Confused}

Shafak's heroine, Peri, struggles to understand herself and the people around her while growing up in a house that holds contrasting beliefs concerning Islam: "they were as incompatible as [a] tavern and mosque" (Shafak, 2016, p. 28). Mensur, Peri's father, is ashamed of his wife's behavior and appearance - a typical religious concern in the Middle East. He presumes that their ways are the best, as they "had been born into this culture and swallowed unquestioningly whatever they had been taught" (Shafak, 2016, p. 70). For Selma, Peri's mother, Mensur's behavior reflects of arrogance, violence, and finality of voice. The secular modernists are arrogant because they place themselves outside of and above society, imbued with contempt derived from centuries of long-standing traditions (Shafak, 2016, p. 70). Peri's arguments and discussions with her family members are usually marked by violence, often ending with an abusive exchange of accusations or indifference and silence. Thus, the void formed by Peri's lack of love was filled with resentment instead, as she "learned that there was no fight more hurtful than a family fight, and no family fight more hurtful than one over God" (Shafak, 2016, p. 35).

All her life, Peri has observed her parents in conflict. Still she has never attempted to discover herself or her beliefs until she joins Azur's class to understand the divisive opinions about faith in her family (Shafak, 2016, p. 183). In Peri's ultimate search for true faith, she feels powerless and worthless because she does not consider herself an independent thinker. Being raised by parents that express two opposite facets of their perceived notions of Islam, Peri feels a sense of doubt throughout her life, leading her to have ambivalent thoughts concerning religion. This significantly affects Peri's identity, especially since religion is an essential role that represents and defines her as a person. As a teenager, Peri flounders between doubt and certainty. Her journey during this time is part of a critical. period of exploration and the development of self-awareness. As Lopez et al. (2011) explain that teenagers explore social categories, distinctions, and 
AWEJ for Translation \& Literary Studies Volume, 6 Number 1. February 2022

identification within specific social groups. Their exploration results in their adaption of other social identities, such as a religious identity. They become increasingly aware of the significance and meaning of various religious traditions, potentially causing their religious identification to increase over the their teenage years (Lopez et al., 2011).

Peri's close relationship with her father places her in a difficult position regarding her mother's ideas and views about Mensur. That is, her beloved father is merely a sinner, an "infidel" (Shafak, 2016, p. 108), in Selma's eyes. Indeed, Mensur encourages Peri to seek an education abroad and to search for truth in science to save herself from her society's ignorance. This constant conflict between Peri's father and mother affects Peri's religious beliefs:

"Yet she could not for a moment believe that the religious teachings her mother held sacred and her father railed against belonged to the same God ... [However] she knew, from all that she had been taught, that Allah was the one and only" (Shafak, 2016, p. 21).

Her adoration for Mensur leads her to side with him in all matters related to faith, but her fear of losing him drives her to take Selma's side after he has a heart attack. To Selma, however, this is a punishment from Allah because he is an "infidel" (Shafak, 2016, p. 108). On that day, Peri prays for the first time by imitating Selma in order to save Mensur. Thus, Peri lives a double life during her teenage years, hiding her faith from Mensur, while remaining loyal to her oath to God. According to Lopez et al., (2011) family and religious identities overlap suggesting that these factors may instigate changes in one's identity and affect other identities, thus influencing how adolescents explore their religious, ethnic, and family identities. These factors may cause teenagers to explore new ideas or experience crises that challenge their existing notions of religion and relationships. In Peri's case, the religious conflict in her family places her at a crossroads. Instead of inheriting Islam's true, moderate beliefs and practices, she inherits the conflicting views between two streams: "culturally she was a Muslim, no doubt. Yet the number of prayers she had learned by heart would not exceed the fingers of her hand" (Shafak, 2016, p. 393). She is a Muslim who never practices religion, but "her relationship with Islam had not expired. Her confusion was a continuing affair. Alive. Perpetual. If she stood anywhere at all, it was with the bewildered" (Shafak, 2016, p. 393).

Peri always feels "a gap between her and the ways of the religion printed on her pink ID card" (Shafak, 2016, p. 122), especially as she experiences gender discrimination. During her period of faith, the young Peri prefers to pray with her friends in a mosque "amidst a congregation" (Shafak, 2016, p. 121) instead of praying alone "to be pure, monophonic" (Shafak, 2016, p. 121). However, her thoughts about this become tainted by a middle-aged man, who followed them to the mosque and asserted that "girls should pray at home," while "his eyes [traveled] over the contours of their breasts" (Shafak, 2016, p. 121). Undergoing gender discrimination at such a young age, especially in connection to her ongoing religious journey, impacts Peri's self-image as a woman, as well as her understanding of a woman's status in Islam. Even though Peri responds to the man, "This is Allah's House, it's for everyone," she later poses the question, "So mosques belong to men" (Shafak, 2016, p. 121)? This illustrates her refusal to accept certain assumptions that many Muslim women often experience, as they, in Aziz's (2012) words, "face unique forms 
AWEJ for Translation \& Literary Studies Volume, 6 Number 1. February 2022

of discrimination at the intersection of religion, race, and gender" they "are falsely stereotyped as meek, powerless, oppressed" (p.192). Peri experiences a solid positional switch to being disappointed in the Imam (i.e., the person who leads prayers in a mosque), who had overheard the conversation in passing but "said nothing to defend them" (Shafak, 2016, p. 121). Instead of encouraging young girls to enter mosques and pray, society despises them based on gender bias, thus violating their rights in the name of religion by preventing them from praying inside a mosque. However, all women have an similar equal right to practice religion and share a similar role with men in this context. Thus, characterizing religious practices or places based on gender is considered discrimination against women and negatively influences religion.

While the expression of virtue is a religious practice expected from all Muslims, men and women, as the Qur' an commands that Muslims lower their gaze, still, in a religious society, some of the males take advantage of their position and distort the image of Islam. This is depicted in the Imam's by behavior when harassing teenage girls near mosques. Hie finds no inhibition to let his "eyes travel over the contours of [the young girls'] breasts" (Shafak, 2016, p. 121). Feeling disgraced because of this incident, Peri becomes more confused and raises several doubts about how religion may be perceived and interpreted. As adverse as it may be, Peri's experience with the "veil" as an intersectional marker of gender and religion, is still comprehensible when compared to other registered women experiences, such as those evoked by Aziz (2012), who discusses how the "veil" can be representative of far more adverse female experiences that have aroused pervasive suspicion of Islam which, she declares, is not merely perceived as oppressive to women's sexuality or freedom of choice, but is expanded into being a dangerous religious "signifier" arousing suspicion in women and linking them to violence and terrorism (Aziz, 2012, p. 192).

Peri has understood the challenges of being a woman in her society since she was a child, having experienced hostile sexism throughout her life. Her first such experience was in her formative years when a man tried to kidnap her from a park (Shafak, 2016). Although Peri does not grasp what happened to her that day until years later, except that she was saved at the last minute by her mother's call asking Peri to return home, this situation had a lasting impact on her. In another experience, Peri encountered harassment at her brother's wedding, when a man stared intently at her: "[It] wasn't the kind of male gaze that conveyed attraction and stopped at that fine line, but one that pushed, insisted, claimed" (Shafak, 2016, p. 219). Although Peri "ma[de] it clear that she was not interested in him ... He seemed not to understand that only a Lilliputian step separated assertiveness from aggression" (Shafak, 2016, p. 219). The man followed Peri and blocked her way to begin flirting, but Peri intercepted him and asserted that he had no "right to bother her" (Shafak, 2016, p. 220). This rejection triggered an "unmistakable hostility," and the man insulted her by calling Peri an "arrogant bitch" (Shafak, 2016, p. 220). Immediately, the man's attitude shifted from admiration to resentment: "How easy it was to switch from liking to loathing. In the kingdom of the East, the male heart, like the orb at the end of a pendulum, swung from one extreme to the other" (Shafak, 2016, p. 220).

Such experiences affect women's self-esteem and mental health, especially young women; thus, Peri feels disgusted toward her body and considers menstruation a punishment. She wishes 
AWEJ for Translation \& Literary Studies Volume, 6 Number 1. February 2022

to be "born as the third son of the Nalbantoğlus. Wouldn't life be easier had she been a boy" (Shafak, 2016, p. 106)? Shafak explains that Peri is, in fact, "convinced that her father's heart attack was, through some circuitous chain of causation in the universe, instigated by her period" (Shafak, 2016, p. 109). Due to gender discrimination that Peri either experiences or observes, she demonstrates a sense of aghast over being a female. This feeling is evident at her brother's wedding when she learns that her brother suspected that his wife was not a virgin. Wondering how a woman's happiness on this special day can turn into a sorrowful experience, Peri watches how the bride is dragged to the hospital against her will to be examined. Her family's persecution of the poor bride impacts Peri personally. For Peri, this kind of tragedy "happened to other people peasants in godforsaken villages, provincials who knew no better. Hers was not a family to get entangled in a virginity test at a ramshackle hospital" (Shafak, 2016, p. 230). As the young bride walked away from the examination room, Peri constantly thought how her parents may have reacted toward her had she been in her sister-in-law's position; she "noticed her hands, manicured and hennaed, and her palms, studded with red crescents ... The marks a young woman digs with her fingernails during a virginity examination" (Shafak, 2016, p. 230). Deeply affected, Peri "felt a seething rage inside ... at the ages-old tradition that determined a human being's worth was between her legs" (Shafak, 2016, p. 231).

One of the main issues that women encounter in such a culture is linking their virtue to men's honor by legalizing violence against women, including murder. Any man who fails to aggressively react towards incidents related to women's "honour" is interpreted as unable to protect himself and his property, of which his women are part. Even educated men are prepared to resort to violence to respond to any doubts they have about their women's virtue. This explains why Peri's father, for example, was involved in the virginity test. His silence indicates his agreement to expose the young woman to the test, a reaction that enrages Peri the most, causing her to feel sympathy for her mother's suffering with her father. She imagines Selma's difficulties and efforts to save her marriage with a man who holds such beliefs: "Peri held her mother's hand, more by instinct than intention" (Shafak, 2016, p. 231). Even though Selma was also involved that night, Peri, for the first time, values her mother's role and appreciates the obstacles she has faced to succeed as a wife and mother. This moment marks Peri's standing in solidarity with the women around her, all of them are victims of tradition, forced to engage in constant battles to fulfill their social role as females in an androcentric society.

Peri, growing up in a culture that manifests conflicting views concerning Islam and women-Peri oscillates between extremism and moderation, certainty and doubt, liberty and captivity, from one parent's side to the other, ever anxious about being considered ignorant by her father or an "infidel" by her mother. Thus, Peri constructs a confused self-image and identity about an essential aspect of her personality (i.e., religion), which leads her to become a dubious woman consumed by her inability to reconcile what others think of her and what she thinks of herself. In Shafak's words, Peri reached a point where she could "no longer tell how much of each day was defined by what was wished upon her and how much of it was what she really wanted" (Shafak, 2016, p. 4).

Arab World English Journal for Translation \& Literary Studies 
AWEJ for Translation \& Literary Studies Volume, 6 Number 1. February 2022

Prismatic Identities or Authentic Selves? Elif Shafak's Three Daughters of Eve

Al-Zahrani\& Al-Sharqi

\section{Shirin, the Sinner}

In her novel, Shafak depicts Shirin as "strong, stubborn. A natural-born warrior" (Shafak, 2016, p. 488) who challenges the stereotypes associated with being both a woman and Muslim. She struggles to be recognized as independent, powerful, and competent. Despite society's mistreatment of her, she remains willing to maintain her autonomy. Although Shirin continuously resists the stereotype of a helpless woman who needs to be rescued, when she and Azur start their relationship, many of the other characters feel responsible for protecting her, even though "they were two consenting adults, neither exploiting the other" (Shafak, 2016, p. 460). Shirin is treated by Troy, a student at Oxford, whose only motive is to protect Shirin from Azur, as a minor woman who needs to be rescued. Troy represents the protective male figure. His behavior emphasi zes the social stereotype that women are weak, powerless, and need a male figure, or higher authority, to protect and help them. Troy's protective attitude towards Shirin might be part of Western countries' attempt, as Razack (2004) argues, to regulate Mus lim migrant communities' conduct as a result of the the hierarchical relationship and irreconcilable clash between the West and Islam. Such regulatory acts by Troy, representing the civilized European who must protect and instruct culturally inferior people", Shirin, can, in many ways, be equated with the violence that these women suffer at the hands of their men and families (Razack, 2004, p.130).

Shirin herself felt like an outsider "[H]er family [were] from Iran, but they had moved around so much she didn't feel like she belonged anywhere" (Shafak, 2016, p. 115). In Iran, "The Mullahs and the morality police silence [women]" (Shafak, 2016, p. 356), and her homeland's higher authority uses Islam to oppress and govern them. Her father, for example, s tates, "It's killing ... He meant the regime" (Shafak, 2016, p. 150). Shirin only visits Iran once, when she travels with her mother to bury her grandmother, who "adored [Shirin], her first grandchild. Neighbors said till her last breath she hoped we'd come back. That's home for [her]! Buried with Mamani in Tehran" (Shafak, 2016, p. 150). Shirin witnesses the loss of familial attachment as she observes her parents struggle. She did not choose to live in exile; it "was Baba's dream, not mine, and here I am as British as a treacle tart but as out of place as a stuffed date cake" (Shafak, 2016, p. 150)!

Shirin associates Islam with eviction, her family's lives as immigrants, and the Iran regime, which she blames for having to leave her country and live her entire life in exile. Shirin states, "Before you know it, it's a republic of headscarves. That's why my parents left Iran: your small piece of cloth sent us into exile" (Shafak, 2016, p. 417)! Thus, Shirin adapts to Islam's political interference, considering Islam is "The Mullah" in Iran (i.e., an Islamist terrorist group). Shirin's inner conflict initially pushes her away from recognizing her religious/cultural identity as an Iranian Muslim. She was the girl with a "short skirt, high heels, heavy makeup ... And she surely didn't look Iranian" (Shafak, 2016, p. 143). According to Sadeghi (2008), misveiling is a form of self-representation some young women in Iran choose by wearing fashionable hijab to "accommodate themselves to Iranian legal requirements" (Sadeghi, 2008, p. 250). It implies a kind of political resistance: it is a reaction toward the unwanted consequences of society's Islamization, including compulsory veiling. This issue has been part of what Llyod Ridgeon defines as "the problem" many Iranians have with "identifying" aspects of their "cultural authenticity", as they oscillate between "the benefits and harms of indigenous customs and culture on the one hand and

Arab World English Journal for Translation \& Literary Studies 
AWEJ for Translation \& Literary Studies Volume, 6 Number 1. February 2022

of the merits and dangers of Western ideas and practices on the other hand" (Ridgeon, 2017, p. 59).

Shirin challenges all the aspects that restrict her from meeting the expectation of what an Iranian Muslim woman should be; otherwise, she "would be a bad influence" (Shafak, 2016, p. 152). However, she refuses all the stereotypes that restrict her within that framework and chooses to be the girl with a "short skirt, high heels, [and] heavy makeup" (Shafak, 2016, p. 143). Through her physical appearance, Shirin declares her independence from any stereotype that aims to limit her, whether regarding religion, gender, or nationality. As a "free spirit," Shirin yearns to find her voice without barriers, so she battles the stereotypes that conceal her opinions and female identity.

Women are expected to be silent. To some people within Muslim society, women's voices are considered Awrah-haram, ${ }^{1}$ which explains Shirin's rebellion against the hijab, she sees as restricting her from being "a free spirit." For Shirin, "girls who sincerely believe they must cover themselves so as not to seduce men, they silence us from inside" (Shafak, 2016, p. 423). Alongside her argumentative swagger concerning concepts about God, Islam, and Muslims, "She was particularly allergic to young Muslim women who covered their heads out of personal choice" (Shafak, 2016, p. 422). Shirin's exasperation about religion is noticeable to those around her, as she never puts any effort into hiding it. Since their first meeting, Peri sensed Shirin's cynical glimpse at her mother's headscarf and long, loose-fitting coat; Shirin seemed to "disdain women who covered their heads - a disdain she felt no need to hide" (Shafak, 2016, p. 144).

Shirin shares Peri's confusion regarding Islam and those who in appearance represent religion, but who in reality are extremists, racists, or sexists. Like Peri, Shirin is anxious to belong or identify with a group but feels frustrated that "there are crazies out there doing really sick stuff in the name of religion, our religion"(Shafak, 2016, p. 417). During the 9/11 attack, Shirin worried about its negative impact on all Muslims worldwide. She thought that they would be "vilified" because "some depraved bastards believe they'll go to paradise if they kill in the name of God" (Shafak, 2016, p. 295). Shirin expressed concern about the image of Muslims in the West, as they argued about how "Religion fuels intolerance, and that leads to hatred and that leads to violence. For months, years even. Journalists, experts, academics" (Shafak, 2016, p. 296). According to Bayat and Herrera (2010), modern worldwide politics plays a significant role in constructing Islamic identity among Muslim youth. "Whether as radical or moderate, principled or pragmatic," after 9/11, the generation of young Muslims has experienced an overwhelming amount of politics and the West's preconception with Islam and Muslims (Bayat \& Herrera, 2010, p. 21). Shirin's lost faith in Islam is most likely due to the Islamic image portrayed by people who exclusively view or interpret religion according to their misconceived notions of terms. She describes this phenomenon as "the arrogance of so-called 'experts' or 'thinkers' or the self-serving platitudes of imams and priests and rabbis" (Shafak, 2016, p. 246). Alongside these opinions, the Iranian regime and terrorist groups distort the image of Islam, which is also Shirin's image. As Mona states of Shirin, "you are - a self-hating Muslim" (Shafak, 2016, p. 419). These factors may explain Shirin's lost belief in religion and religious people: "while she laid into all denominations, it was the faith she was brought up in that she criticized most" (Shafak, 2016, p. 422).

Arab World English Journal for Translation \& Literary Studies 
AWEJ for Translation \& Literary Studies Volume, 6 Number 1. February 2022

Shirin being a women, Muslim, and Iranian, struggles to free herself from various forms of discrimination, aiming to rid herself of these vectors, and identify herself as a "free spirit." However, she also expresses an eagerness to enlighten herself about her religion, primarily because of Mona. Shirin rents a house to live with Mona and Peri and discover Islam. According to Peri, Shirin and Mona "had been selected for this bizarre social experiment" without her knowledge (Shafak, 2016, p. 423).

\section{Mona, the Believer}

Mona is an Egyptian-American Muslim who (unlike Peri and Shirin) is incredibly proud of her religious identity, as is reflected in her "headscarf wrapped neatly in a turban style" (Shafak, 2016, p. 115). Although Mona was born in the United States, she moved to Cairo with her family when she was about ten years old to fulfill her father's wish that "the children should be raised in Muslim culture" (Shafak, 2016, p. 178). Unfortunately, they had to return unexpectedly to the states because of their complex life in Egypt (Shafak). Although she grew up in a Muslim household that prided itself on Islamic identity, Mona's family never forced her to wear a hijab and always gave the children "the option" to choose. While her sisters followed a different path, Mona covered her head, a decision she considered "personal... a testimony to [her] faith," giving her a sense of "peace and confidence" (Shafak, 2016, p. 189).

Mona and Shirin's continuous debate illustrates that - due to Islamophobia-Muslim women, including Mona, endure discrimination because of their choice to wear a hijab. Mona explains how she has been bullied, called names, pushed off a bus, and treated as if she were dumb simply because of her headscarf. Although "It's just a small piece of cloth" (Shafak, 2016, p. 416), Mona explains how she faces profound challenges because she wears it: "Every day I have to defend myself when I've done nothing wrong. I'm expected to prove that I'm not a potential suicide bomber. I feel under scrutiny all the time" (Shafak, 2016, p. 417). Furthermore, Mona is even stereotyped as an oppressed, helpless woman, who must be saved from her religion. Even though she is proud and confident to be wearing a hijab, people (including women) treat her as a submissive person who needs to be saved. These views are echoed in Bilge's argument about Muslim women's veil as an embodiment of the dichotomous interplay between Western hegemonic imaginaries and these women's perceptions of themselves as free-willed subjects. Deeply rooted in colonial history, this dichotomous framing of the Muslim veil, as Bilge states, presents Muslim women as being caught between colonial domination and anti-colonist national resistance (Bilge, 2010, p.14).

Thus, Mona, who chooses to wear a hijab as a personal decision, finds herself in a difficult position when she tries to justify her choice to others. To express her views, Mona founds the "Oxford Feminist Squad" movement and criticizes how people in the West assume that only women in "Pakistan, Nigeria, [and] Saudi Arabia" need feminism "but not Britain. Surely not Oxford." And yet, she insists, a "freshwoman in Oxford needs feminism just as much as a peasant mother in rural Egypt" (Shafak, 2016, p. 177)! It is challenging for some to "match the term [feminist] with the girl's outlook" (Shafak, 2016, p. 177). Interested in alternative forms of feminism, Mona joins a diverse movement that emerges in opposition to Western or "white" feminism, which, as Crenshaw asserts, speaks on behalf of minority women (Crenshaw, 1989). 
AWEJ for Translation \& Literary Studies Volume, 6 Number 1. February 2022

Viewed from the perspective of intersectional feminism, arguably, Mona's version of feminism concerns all women, including Muslim women. As Mona asserts, "I am a Muslim feminist, and if some people think that's impossible, it's their problem. Not mine" (Shafak, 2016, p. 177). Despite Mona's strong presence and her confidence in her identity as a Muslim woman, people in her society, assuming she is weak, offer her help. She repeatedly emphasizes that she is independent and has the right to choose, including which religion to follow and what she wants to wear, just like any other woman. While society treats her as an obedient woman, ignoring her enthusiasm, she insists "that Islam's treatment of women [is] unacceptable ... if [a man had been] born a woman into this faith he would have abandoned it at the speed of light" (Shafak, 2016, p. 143). From an Islamic feminist point of view, as Sevda Clark asserts, the expression of "saving a Muslim woman" or seeing the "Muslim woman [as] a victim" is a remnant of colonial power (Clark, 2007, p. 36), a perception deeply rooted in English Romantic literature, as when "personified in the Byronic tale of the white man rescuing the Turkish harem girl from her Muslim-male oppressors" (Clark, 2007, p. 36). These assumptions of Muslim women and Islam have been spread along with the expansion of colonialism. Mona resists these deeply embedded assumptions that Muslim women are deprived, suppressed, and need to be liberated from the prison of their religion and the hijab. She instead attempts to formulate a specific brand of feminism that suits Muslim women and combats the kind of Western feminism that devalues, discriminates against, or denies other women's experiences.

In A quiet revolution: The veil's resurgence, from the Middle East to America (Ahmed, 2011), Laila Ahmed suggests that the hijab worn by Muslim women in the American society is a means to express political solidarity with Muslims around the world who suffer from American imperialism, and also as a language for defining women's independence against the postcolonial state. Ahmed maintains, there "are meanings that the hijab can come to have only in societies that declare themselves committed to gender equality and equality for minorities" (Ahmed, 2011, p. 236). These politically-oriented meanings are expressed in Mona's words, who explains that for her, the hijab does not restrict her: "If I, with my headscarf, don't challenge stereotypes, who's going to do it for me? People look at me as if I'm a passive, obedient victim of male power. Well, I'm not. I have a mind of my own. My hijab has never got in the way of my independence" (Shafak, 2016, p. 189). Mona believes that women have the right to choose to be veiled or unveiled, and she challenges the stereotypes that mold women who wear hijabs into a particular lifestyle. Her rejection of this image allows Mona to grow into a strong, self-confident woman who is at "peace with who [she is]" (Shafak, 2016, p. 179). Open to different experiences and diverse cultures, Mona does not consider religion or the hijab to be obstacles, and she reflects these values throughout her life. As a feminist, Mona is involved in a series of volunteer organizations: Help to the Balkans Society, Friends of Palestine Society, Sufi Studies Society, Migration Studies Society, the Oxford Islamic Society (where she was one of the leading members), and "she was also about to launch a "hip-hop society" because she loved the music" (Shafak, 2016, p. 179).

\section{Conclusion}

This study examines the religious, ethnic, and gender assumptions of female Muslims by providing an analysis of the three protagonists (the believer, the confused, and the sinner) from Elif Shafak's novel, Three Daughters of Eve. By employing the theory of intersectional feminism, this study 
AWEJ for Translation \& Literary Studies Volume, 6 Number 1. February 2022

Prismatic Identities or Authentic Selves? Elif Shafak's Three Daughters of Eve

Al-Zahrani\& Al-Sharqi

illustrates how stereotypes intertwine to create unique experiences, values, beliefs, and challenges in women's lives. Our research makes a significant contribution to the literature because it confronts the modern assumptions of Western society's ideas about women and Islam by discussing how distinct self-identities form and function in society, despite sharing some similar characteristics. The novel promotes an inclusive form of feminism that elevates diversity and inclusivity among women. Shafak's work serves to boost the voices of all women by revealing discrimination's many guises to illustrate how women find ways to project their unique voices and resist oppression. Furthermore, intersectional feminism provides a framework for understanding the complex nature of identity and self-understanding, especially among women minorities in the Middle East.

\title{
End Notes
}

1. 'Awrah' is an Arabic term, which, according to Lisan-Al-Arab (Ibn-Manzur), denotes something hidden/a secret. The term also means imperfection, weakness, or blemish. A person's awrah refers to their body parts that must be covered. Exposing the intimate parts of the male and female body is considered unlawful. Although the term 'awrah' is used in the Quran in various contexts, it is generally used to describe body parts that should not be revealed in public.

\begin{abstract}
About the Authors
Shua'a Alzahrani is an English instructor at Technical and Vocational Training Corporation, Saudi Arabia. She received her MA from the Department of European Languages and Literature at King Abdulaziz University, Saudi Arabia in 2020. Her research interests are in the area of postmodern literature, women studies, and the representation of middle eastern women in literature.ORCID ID. https://orcid.org/0000-000-9520-488X
\end{abstract}

Laila Mohammed Al-Sharqi is an associate professor of English in the Department of European Languages and Literature at King Abdulaziz University, Saudi Arabia. She received her Ph.D. in Cultural Studies from the University of Nottingham. Her research interests include postmodern literature, literary theory, gender studies. "Magical realism as a feminist discourse in Raja Alem's Fatma" and "Twitter Fiction: A new creative literary landscape" are examples of her research. ORCID ID. https://orcid.org/0000-0001-8142-1525

\section{References}

Ahmed, L. (2011). A quiet revolution: The veil's resurgence, from the Middle East to America. Yale University Press.

Aziz, S. F. (2012). From the oppressed to the terrorist: Muslim-American women in the crosshairs of intersectionality. Hastings, race and poverty law journal, 9(2), 191-264. http:// scholarship.law.tamu.edu/facscholar/ 100

Bădulescu, A. (2018). Eve between two worlds. Arhipelag XXI Press.

Bayat, A., \& Herrera, L. (2010). Being young and Muslim: New cultural politics in the global south and north. Oxford University Press.

Arab World English Journal for Translation \& Literary Studies 
AWEJ for Translation \& Literary Studies Volume, 6 Number 1. February 2022

Carastathis, A. (2008). The invisibility of privilege: A critique of intersectional models of identity. Les ateliers de l'éthique, 3(2), 23-38. https://doi.org/10.1080/10.7202/1044594ar

Carastathis, A. (2013). Identity categories as potential coalitions. Signs, 38(4), 941-965.

Clark, S. (2007). Female subjects of international human rights law: The hijab debate and the exotic other female. Global Change Peace \& Security, 19(1), 35-48. https://doi.org/10.1080/14781150601138067.

Collins, P. H. (2015). Intersectionality's definitional dilemmas. Annual Review of Sociology, 41(1), 1-20. https://doi.org/10.1146/annurev-soc-073014-112142

Collins, P. H., \& Bilge, S. (2016). Intersectionality. (p. 158). Polity Press.

Crenshaw, K. (1989). Demarginalizing the intersection of race and sex: A black feminist critique of antidiscrimination doctrine, feminist theory and antiracist politics. The University of Chicago Legal Forum, 140(1), 139-167. https://doi.org/10.4324/9780429500480-5

Hooks, B. (1982). Ain't I a woman: Black Women and Feminism. United Kingdom: Pluto Press. Ibn Manzoūr, Muhammad Ibn Mukarram. (1312). Lisan al-Arab. Bayrut: Dar Sadir.

Lopez, A. B., Huynh, V. W., \& Fuligni, A. J. (2011). A longitudinal study of religious identity and participation during adolescence. Child Development, 82(4), 1297-1309. https://doi.org/10.1111/j.1467-8624.2011.01609.x

Mirza, H. S. (2012). A second skin': Embodied intersectionality, transnationalism and narratives of identity and belonging among Muslim women in Britain. Women's Studies International Forum, 36 (1), 5-15.

Nihad, M. (2019). Elif Shafak: The voice of the other. Opcion, 21, 2900-2913.

Oswald, D. L., Franzoi, S. L., \& Frost, K. A. (2013). Experiencing sexism and young women's body esteem. Journal of Social and Clinical Psychology, 31(10), 1112-1137. https://doi.org/10.1521/jscp.2012.31.10.1112

Razack, S. (2004). Imperiled Muslim women, dangerous Muslim men, and civilized Europeans: Legal and social responses to forced marriages. Feminist legal studies, 12, 129-174. https://doi.org/10.1023/B:FEST.0000043305.66172.92

Ridgeon, L. (2017). Ahmed Kasravi and "Pick-Axe Politics": Neckties and literature as western tools of cultural imperialism. Journal of the British Institute of Persian Studies, 54(1), 59-72. https://doi.org/10.1080/05786967.2016.11882301

Sadeghi, F. (2008). Negotiating with modernity: Young women and sexuality in Iran. Comparative Studies of South Asia, Africa and the Middle East, 28(2), 250-259. https://doi.org/10.1215/1089201x-2008-003

Sârbu, S., \& Kosa, M. (2019). The figure of the seducer in Elif Shafak's Three Daughters of Eve. InterCulturalia 2018, 149.

Shafak, E. (2016). Three Daughters of Eve (p. 212). United Kingdom: Penguin.

Arab World English Journal for Translation \& Literary Studies 